UNRAM Law Review is licensed under a Creative Commons Attribution 4.0 International License, which permits unrestricted use, distribution, and reproduction in any medium, provided the original work is properly cited. p-ISSN: 2548-9267 | e-ISSN : 2549-2365, Open Access at : http://unramlawreview.unram.ac.id/index.php/ulr

\begin{tabular}{c|c|c|c|c|}
\hline Volume & Issue & Page & April & p-ISSN: 2548-9267 \\
\hline 4 & 1 & $26-32$ & 2020 & e-ISSN : 2549-2365
\end{tabular}

\title{
Status of the Separated State Assets into BUMN Persero
}

\author{
Ghora Putra Bafelanna \\ Universitas Airlangga Surabaya \\ Jl. Airlangga No. 4-6, Surabaya \\ Email: ghoraputra3@gmail.com
}

\begin{abstract}
The regulation of the status of state finances in the State owned enterprise (BUMN) environment in the BUMN Law and the Law on State Finance shows that there is a very significant difference in the status of state separated state assets from BUMN. The applied problem approach in this legal research is statutes approach. The Principle of State Assets Separation in the form of Equity Participation in Persero is also supported by the existence of a Fatwa from the Supreme Court Number WKMA / Yud / 20 / VIII / 2006 concerning the Separation of BUMN assets from state assets. The contents of the fatwa are related to Article 1 number 1 of the BUMN Law and Article 4 paragraph (1) of the BUMN Law which, according to the Supreme Court, is a more specific law concerning BUMN, it is clearly said that enterprises' capital which originating from separated state's earning and expenses shall be based on the principles of a sound corporate.
\end{abstract}

Keywords: BUMN; Corporates; State assets.

\section{INTRODUCTION}

State-Owned Enterprises (hereinafter abbreviated as: BUMN) is one of the agents of economic activity in the national economy based on economic democracy that has important role in managing the national economy in order to realize the welfare of the society. The presence of BUMN is a concrete step taken by the Government in realizing the ideals of the nation to enhance public welfare.

Article 1 number 1 of Law Number 19 of 2003 concerning BUMN, is stated that BUMN is a business entity which entire or most of its capital is owned by the State through direct participation from the separated assets of the state. Article 1 number 2 of the BUMN Act also explicitly formulates that the company, here in after referred to as Persero, is a BUMN in the form of a Limited Liability Company which capital is divided into shares which are wholly or at least $51 \%$ (fifty one percent) of shares owned by the State which main purpose is to generate profit. In It can be concluded that BUMN is a business entity that carries out business activities and its capital is overall or at least $51 \%$ (fifty one percent) of its shares are owned by the State.

With regards to capital, BUMN Persero is a civil law object that requires capital to carry out all its business activities. Article 4 paragraph (1) of the BUMN Law stipulates that its capital is and originates from separated state assets. In addition, Article 4 paragraph (2) of the BUMN Act also provides limitation on the inclusion of state capital in the context of establishment or participation BUMN originating from: (a) the State Revenue and Expenditure Budget; (b) Reserve Capitalization; (c) Other sources. BUMN activities 
Limited in the form of Limited Liability Company are a form of economic activity that is carried out continuously (regelmatig) and openly (openlijk) in order to obtain profits.

The emerging issue is related to the management of state finances in BUMN. Recently, almost every day the mass media presents cases involving corruption in various Government agencies from the central to regional levels related to problems in the management of state finance. State finance in a broad sense includes the state financial budget in state-owned companies and so on. Whereas the definition of state finance in narrow sense only covers every legal entity authorized to manage and account for it ${ }^{1}$.

Regarding state finance, Article 1 number 1 of Law Number 17 of 2003 (hereinafter abbreviated as: State Finance Law) provides a definition of State Finance is all the rights and obligations of the state that can be valued in money, as well as everything in the form of money or in the form of goods which can be owned by the state in connection with the implementation of these rights and obligations. Furthermore Article 2 of the Law on State Finances provides the scope referred to in state finances, namely: a) the right of the state to impose taxes, issuing and circulating money, and make loans; b) the state's obligation to carry out government's public service tasks and pay for the third party bills; c) state revenue; d) state expenditure; e) regional revenue; f) regional expenditure; g) state assets / regional assets which are managed by other parties in the form of money, securities, receivables, goods, and other rights that can be valued with money, including assets that are separated in state /regional companies; h) the assets of other parties controlled by the government in the context of carrying out governmental duties and / or public interests; i) Assets of other parties obtained using facilities provided by the government.

In principle, the substance of state finance can be seen from both broad and narrow perspectives. State finance in a broad sense includes: (1) APBN; (2) APBD; (3) state finances in BUMN / BUMD. While state finances in the narrow sense only covers state finances managed by each legal entity and are accounted for individually ${ }^{2}$.

In terms of separated state assets in BUMN Persero, according to Article 2 letter $g$ of the State Finance Law, that the separated state assets are still considered as state finances ${ }^{3}$. Meanwhile according to the description of Article 4 paragraph (1) BUMN Law, separation is refers to the separation of state assets from the State Revenue and Expenditure Budget to be used as state capital participation in BUMN for further development and management is no longer based on the State Revenue and Expenditure Budget system. However its guidance and management are based on sound company principles. Thus, by comparing the articles contained in the BUMN Law and the Law on State Finance the separation problems in managing state finances will appear

Regulation of the status of state finances in the BUMN environment in the BUMN Law and the Law on State Finance shows that there is a very significant difference in the status of state assets separated from BUMN.

\section{METHOD}

This study applying normative juridical approach which uses secondary data as the main source obtained through library research. The problem approach used is the statute approach because there is a contradiction (antinomy) between laws and regulations related to research discussion. A statue approach is a legislative approach that is examining all laws and regulations

1 Adrian Sutedi. (2012). Hukum Keuangan Negara. Jakarta: Sinar Grafika, p. 10.

2 Muhammad Djafar Saidi. (2008). Hukum Keuangan Negara. Jakarta: Rajawali Pers, p. 8.

3 Arifin P. Soeria Atmadja. (2009). Keuangan Publik Dalam Perspektif Hukum, Teori, Praktik, dan Kritik. Jakarta: Ra jawali Press, p. 17. 
related to the legal issues being addressed ${ }^{4}$. The data used in this study were obtained from library research, data collection technique utilizing various literatures in the form of legislation, books, scientific works, papers, articles, lecture materials, mass media and other sources.

\section{ANALYSIS AND DISCUSSION}

\section{Principles of State Assets Separated at BUMN Persero}

Article 1 number 2 of the BUMN Law states that Persero is a BUMN in the form of a Limited Liability Company which capital is divided into shares that are all or at least 51\% (fifty one percent) owned by the Republic of Indonesia. It main purpose is to pursue profit. In the case that the Persero is a Limited Liability Company, the Persero is viewed as a legal entity (rechtpersoon) that is independent and has its own rights and obligations, including those related to assets owned by the company, regardless of the assets of its founders and their management. The concept of segregation of assets in Persero also applies to the state as a public legal entity, with the state participating in equity participation in a Persero. Further, the state is automatically considered as a subject of private law ${ }^{5}$.

Article 11 of the BUMN Law states that applied BUMN provisions and principles must be in accordance to limited liability companies'.. Therefore, based on Article 3 paragraph (1) of Law Number 40 of 2007 concerning Limited Liability Companies (hereinafter abbreviated as: PT Law), which states that shareholders of the company are not personally responsible for the agreements made on behalf of the Company and are not responsible for the losses of the Company exceeds the shares owned, it is in accordance with the concept of BUMN Persero, namely the principle of separate legal entities and limited liability.

In line with this, Article 1 number 10 of the BUMN Law states that the separated state assets are those originating from the State Revenue and Expenditure Budget (APBN) to be used as state capital participation in Persero and / or Public Corporation and other limited liability companies. In addition, Article 4 paragraph (1) of the BUMN Law states that BUMN capital is and originates from separated state assets. Elucidation of Article 4 paragraph (1) of the BUMN Law also states that what is intended by separation is the separation of state assets from the State Revenue and Expenditure Budget to be used as state capital participation in BUMN for further development and management is no longer based on the State Budget Revenue and Expenditure system. However its guidance and management are based on healthy company principles.

Article 1 number 1 of the Law on State Finances formulated that state finance refers to all rights and obligations of the state that can be valued in money, as well as everything in the form of goods that can be owned by the state in connection with the implementation of those rights and obligations. In addition, Article 2 letter $g$ of the State Finance Law adds to the understanding that referred to state assets include state assets /regional assets that are managed by themselves or by other parties in the form of money, securities, receivables, goods, and other rights that can be valued with money, including assets separated in state / regional companies. So with the formulation of this article, separated state assets which are included as state capital participation in the Persero are still state assets.

So that in this case there are two equally strong views, namely the legal domain the BUMN Act views that state assets separated through equity participation in the Persero have become

4 Dirdjosiswono. (1996). Pengantar Ilmu Hukum. Jakarta: Raja Grafindo Persada, p. 6.

5 Amalia Ghinarahmatina. (2017). "Akibat Hukum Pemisahan Kekayaan Negara Melalui Penyertaan Modal". Lex Journal: Kajian Hukum \& Keadilan, Universitas Dr. Soetomo, Surabaya, 4. 
assets in the Persero, but in the legal domain the State Finance Law separated state assets remain part from state finances.

The separated state's asset which becomes capital participation in the company is one of the embodiment forms of the state to implement the concept of welfare state (welfare state) ${ }^{6}$. This is in accordance with Article 33 paragraph (2) of the 1945 Constitution of the Republic of Indonesia (hereinafter abbreviated as "1945 Constitution of the Republic of Indonesia"), that production branches which are important for the state and which control the livelihoods of the public are owned by the State. The form of separated state assets is one of the elements of state finance that is managed as well as possible. Arifin P. Soeria Atmadja said that: "This separation of state assets contains meaning and consequences, namely the Government setting aside state assets to be used as capital participation capital to be used as capital for the establishment of public companies or companies, or to add and strengthen capital structure of public companies or limited liability companies in increasing their business activities" 7 .

The definition of state assets separation according to Article 1 number 10 of the BUMN Act, is those assets originating from the State Revenue and Expenditure Budget (APBN) to be used as state capital participation in Persero and / or Public Companies and other limited liability companies. Furthermore, in the elucidation of Article 4 paragraph (1) of the BUMN act, separated state assets are state assets sourced from the State Revenue and Expenditure Budget to be used as capital participation of the state in managing the separated state assets various obstacles arise, among others related to the state financial status that has been separated and become capital in the state company. Persero, which is supposed to be a private legal entity under the definition of Article 1 number 1 of the State Treasury Law, "State Treasury is the management and accountability of state finances, including investments and assets that are set apart in the APBN and APBD", makes the company can be examined by public legal entities that is authorized to examine state finances. Thus the company is placed in the public legal domain.

In addition, the principle of State Assets Separation in the form of equity participation in Persero is also supported by the existence of a Fatwa from the Supreme Court Number WKMA / Yud / 20 / VIII / 2006 concerning the Separation of BUMN assets from state assets. The contents of the fatwa are related to Article 1 number 1 of the BUMN Law and Article 4 paragraph (1) of the BUMN act which, according to the Supreme Court, is a more specific law concerning State-Owned Enterprises, it is clearly said that state capital originating from assets that have been separated from the State Revenue and Expenditure Budget should not be based on the State Revenue and Expense Budget system but should be based on sound corporate principles, according to the Supreme Court that the receivables owned by the State Owned Enterprises are not part of the receivables from the state. It is also in accordance with the Decision of the Constitutional Court Number 77 / PUU-IX / 2011, according to the Supreme Court that the BUMN Act is more specifically positioned than the State Finance Act (lex specialis derogat legi generali) thus, Article 2 letter g of the State Finance Act is considered not binding legally.

In the implementation in management level, the state cannot completely release the control over the management of the separated state assets. But in fact that in managing assets of the company, it is entirely the authority of the company itself, but in this case the state as shareholders can carry out supervision role, the same position as other individual shareholders. Associated with the supervision referred to in the Constitutional Court Decision Number 62 / PUU-XI / 2013, the supervision of a public institution should only limited at the representative

6 Arifin P Soeria Atmadja. Op.Cit., p. 84.

7 Ibid, p. 115. 
of the state in the company as the shareholder, so that examination by public institution does not include the assets of the company.

\section{Status of State Assets Separation into BUMN Persero}

One of the debates about the definition of state assets separation from BUMN is caused by the unsynchronized between one Act and another Act, namely the BUMN Act and the State Finance act.

Article 1 number 2 of the BUMN Law states that Persero is a BUMN in the form of a limited liability company which capital is divided into wholly or at least $51 \%$ (fifty one per cent) of its shares owned by the Republic of Indonesia which main purpose is to pursue profit. Furthermore Article 11 of the BUMN act also stipulates that all provisions and principles that apply to limited liability companies as regulated in the PT Law also apply to BUMN Persero.

Whereas Article 1 paragraph 1 of the Law on State Finances states that state finance refers to all rights and obligations of the state that can be valued in money, as well as everything in the form of money or goods that can be used as state property in connection with the implementation of these rights and obligations. Furthermore Article 2 states that state finances as referred to in Article 1 number 1 above includes:

a. The state's right to impose taxes, issue and circulate money and make loans;

b. The obligation of the state to carry out general government service duties and pay bills to third parties;

c. State revenue;

d. State Expenditures;

e. Regional Revenue;

f. Regional Expenditures;

g. Separated state assets / regional assets which are managed by themselves or other parties in the form of securities, receivables, goods, and other rights that can be valued in money, including separated state assets at state / regional companies;

h. The assets of other parties controlled by the government in the context of carrying out governmental duties and / or public interests; and

i. Other parties' assets are obtained by using facilities provided by the government.

Further in it general explanation of the definition and scope of state finances, the Law on State Finance defines state finance more broadly, namely:

"The approach used in formulating state finances is in terms of objects, subjects, processes, and goals. In terms of objects referred to as state finances includes all rights and obligations of the state that can be valued in money, including policies and activities in the field of fiscal, monetary and management of separated state assets, as well as everything in the form of money, or in the form of goods that can be owned the state relates to the implementation of these rights and obligations. From the subject side, definition of state finance covers all objects as mentioned above which are owned by the state, and / or are controlled by the central government, regional governments, state / regional companies, and other bodies related to state finance. From the process side, state finance covers the entire set of activities related to object management as mentioned above starting from policy formulation and decision making to accountability. In terms of objectives, state finance encompasses all policies, activities and legal relations relating to ownership and / or control of objects as mentioned above in the context of administering state government.

Such a broad sector of state financial management can be grouped in the sub-sector of fiscal management, the sub-sector of monetary management, and the sub-sector of management 
of separated state assets. “

Interpretation of Article 2 letter $g$ of the Law on State Finances is that BUMN assets are separated assets. That is, the wealth of BUMN is state finance. Article 2 letter $g$ does not mean that the separated state assets are shares, because shares have been included in securities as stated in Article 2 letter g itself which states: "State assets / regional assets that are managed solely or by other parties in the form of money, securities" ". State assets separated from BUMN in the form of birth are in the form of shares owned by the State, not the assets of the BUMN Persero ${ }^{9}$.

In the BUMN act there are several articles which explicitly state that state ownership of Persero is in the form of shares, namely in the phrase:

a) Article 1 number 2 states "shares are owned by the state";

b) Article 4 paragraph (4) states "state ownership of Persero's shares";

c) Article 4 paragraph (6) states "the shares are owned by the state; and

d) Article 14 paragraph (1) states "Persero's shares are owned by the state;

Then the issue of state wealth separated at BUMN Persero which is also considered as state finance was mediated by the Supreme Court Fatwa Number WKMA / Yud / 20 / VIII / 2006 dated August 16, 2006. The Supreme Court Fatwa stated that:

a. Article 1 number 1 of the BUMN Law describes: BUMN is a business entity that is wholly or partly owned by the state through direct participation from the separated state assets; Article 4 paragraph (1) describes: BUMN constitute and originate from separated state assets; and the explanation of Article 4 paragraph (1) said: What is meant by being separated is the separation of state assets from the State Budget to be used as state capital participation in BUMN for further development and management which no longer based on the State Budget system, but the development and management are based on company principles that are healthy;

b. In the aforementioned articles, which are specific laws on BUMN, it is clear to say that BUMN capital from state assets that have been separated from the APBN and consequently their development and management are not based on the APBN system but are based on sound corporate principles; and

c. The same case with Article 2 letter g of the State Finance Law which describes: state finance as referred to in Article 1 number 1 includes "state assets / regional assets that are managed by themselves or by other parties in the form of money, securities, receivables, goods, and rights. other rights that are separated in state / regional companies ", with the existence of the BUMN Law the provisions of Article 2 letter g of the State Finance Law specifically regarding" assets separated in state / regional company "also have no legally binding force.

The fatwa was later strengthened by the Constitutional Court Decision Number 77 / PUUXI / 2011 which in its legal consideration stated explicitly and clearly that:

"BUMN are business entities that have assets separated from state assets, so the authority to manage wealth, businesses, including the settlement of BUMN debts is subject to PT law under the PT Act."

Based on the above, it can be concluded that the BUMN act emphasizes state assets separated as inclusion of Persero's capital by the state in the form of shares is a stock so that it arises

8 Rudhi Prasetya. (1995). Kedudukan Mandiri Perseroan Terbatas Disertai Dengan Ulasan Menurut Undang-Undang No. 1 Tahun 1995 (Cetakan Ketiga). Bandung: Alumnip. 14.

9 Erman Raja gukguk. (2020). Walaupun Keuangan BUMN Bukan Keuangan Negara, KPK, Kejaksaan, dan Kepolisian Tetap Berwenang Memeriksa Korupsi di BUMN. Available from: http://www.ermahhukum.com/dokumen/keungan\%BUMN\%20bukan\%20keuangan\%20negara.pdf. [accessed 2 Februari 2020]. 
juridical consequences that all capital in a Persero manifested in the form of shares. IN other words the existence of BUMN assets must be separated from state finances ${ }^{10}$.

In addition, based on the character and theory of legal entities that have been regulated in BUMN Law and PT Law, it can be concluded that the existing assets of BUMN Persero are the assets of the Persero itself and are not part of the state's finances, because:

a. Separation of assets from state finances is a major characteristic of the Persero's legal entity. Such a concept will also relate to the ability of the Persero to exercise all rights and obligations arising from the agreements made as referred to in Articles 1653 and 1654 of the Civil Code.

b. Based on Article 3 of the PT Law, the Limited Liability Company in the form of PT has its own assets separate from the assets of the shareholders. This concept is also related to shareholder's responsibility which is limited only to the shares owned by the Persero.

\section{CONCLUSSION}

Wealth that is separated from BUMN Persero cannot be referred to as State assets, this is strengthened by the Constitutional Court Decision Number 77 / PUU-XI / 2011 which states that BUMN are business entities that have assets separated from state assets, so that the authority to manage wealth, business, including settlement of BUMN debts is subject to PT law under the PT Act. In addition, state assets separated from BUMN as capital participation and its form are shares, emerging juridical consequences that all capital in a BUMN is manifested in shares or in other words the meaning of BUMN wealth must be separated from state finances.

\section{Bibliography}

Saidi Muhammad Djafar. (2008). Hukum Keuangan Negara. Jakarta: Rajawali Press.

Dirdjosiswono. (1996). Pengantar Ilmu Hukum. Jakarta: Raja Grafindo Persada.

Amalia Ghinarahmatina. (2017). Akibat Hukum Pemisahan Kekayaan Negara Melalui Penyertaan Modal. Surabaya: Universitas Dr. Soetomo.

Peter Mahmud Marzuki. (2005). Penelitian Hukum. Jakarta: Prenada Media Grup.

Rudhi Prasetya. (1995). Kedudukan Mandiri Perseroan Terbatas Disertai Dengan Ulasan Menurut Undang-Undang No. 1 Tahun 1995 (Cetakan Ketiga). Bandung: Citra Aditya Bakti.

Indra Rahardyan. (2013). Kedudukan BUMN Persero Sebagai Separate Legal Entity Dalam Kaitannya Dengan Pemisahan Keuangan Negara Pada Permodalan BUMN. Yogyakarta: UII.

Arifin Soriea Atmadja. (2012). Hukum Keuangan Negara. Jakarta: Sinar Grafika.

Sulistiowati. (2010). Aspek Hukum dan Realitas Bisnis Perusahaan Grup di Indonesia. Jakarta: Erlangga.

Adrian Sutedi. (2012). Hukum Keuangan Negara. Jakarta: Sinar Grafika.

Gunawan Widjaja. (2005). Hak Individu dan Kolektif Para Pemegang Saham. Jakarta: Forum Sahabat.

10 Indra Rahardyan. (2013). "Kedudukan BUMN Persero Sebagai Separate Legal Entity Dalam Kaitannya Dengan Pemisahan Keuangan Negara Pada Permodalan BUMN”. Jurnal Hukum IUS QUIA IUSTUM, 20(4) , p. 625. 